\title{
Effects of a Chrysochromulina polylepis subsurface bloom on the planktonic community
}

\author{
Torkel Gissel Nielsen ${ }^{1}$, Thomas Kiørboe ${ }^{2}$, Peter Koefoed Bjørnsen ${ }^{1}$ \\ ${ }^{1}$ Marine Biological Laboratory (University of Copenhagen), Strandpromenaden 5, DK-3000 Helsingor, Denmark \\ ${ }^{2}$ Danish Institute for Fisheries and Marine Research, Charlottenlund Castle, DK-2920 Charlottenlund, Denmark
}

\begin{abstract}
During spring (May-June) 1988 an extensive subsurface bloom of the haptophycean flagellate Chrysochromulina polylepis developed in Scandinavian waters (the Kattegat/Skagerrak area). Here we report on the vertical distribution of bacteria, heterotrophic flagellates, ciliates and copepods at a permanent station in the Southern Kattegat during the bloom. At the height of the bloom, the density of C. polylepis reached 60 to $70 \times 10^{6}$ cells $l^{-1}$ in the pycnocline. At this time no potential grazers were present in the subsurface bloom and bacterial production was extremely low. Field and laboratory experiments showed that $C$. polylepis inhibited the activity of planktonic bacteria, ciliates and copepods. During the decay of the bloom, algae were colonized by bacteria and the pycnocline was subsequently re-invaded by heterotrophic flagellates, small aloricate ciliates and copepods. Two weeks after the height of the bloom, the normal pelagic food web structure was re-established.
\end{abstract}

\section{INTRODUCTION}

Algal blooms, dominated by diatoms (spring) or dinoflagellates (autumn), constitute a recurrent event in Scandinavian waters (Lindahl 1983, Edler 1984). They are closely related to seasonal changes in hydrographic conditions (summer stratification, wind-mixing in spring and autumn). During May and June 1988 an unusual bloom of the haptophycean flagellate Chrysochromulina polylepis Manton et Parke developed in the Kattegat and Skagerrak (Fig. 1). This species has previously been recorded from the area (Christensen et al. 1985), but has not hitherto been reported to form blooms (Taylor 1985). The bloom was first observed on May 9, 1988 in the Northern part of Kattegat (Barth \& Nielsen 1989). During the following month it spread along the Swedish and Norwegian coasts to the inshore areas of Kattegat, the Storebælt and the Øresund (Fig. 1). In the Kattegat a subsurface bloom developed in late May, with maximum concentrations of 80 to $100 \times 10^{3}$ cells ml $\mathrm{m}^{-1}$ in the pycnocline.

Severe toxic effects on higher organisms were observed in areas where water containing high concentrations of Chrysochromulina polylepis reached benthic communities or fish farms (Berge et al. 1988, Rosenberg et al. 1988). Laboratory experiments, conducted during the bloom, demonstrated a toxic effect of C. polylepis on eggs and larvae of the ascidian Ciona intestinalis, and on the blue mussel Mytilus edulis (Granmo et al. 1988). The deleterious effects of the bloom caused considerable public concern. From a scientific point of view the observations of such blooms called for explanations of their occurrence, maintenance, degradation and effects on other organisms.

This paper reports on the effects of the bloom on heterotrophic planktonic organisms in the Kattegat area. From the height of the bloom through its decline, we observed the vertical distribution of bacteria, heterotrophic flagellates, ciliates and copepods in relation to the vertical distribution of Chrysochromulina polylepis. We also conducted incubation experiments with the same organisms in water samples containing natural concentrations of $C$. polylepis, to test their influence on growth and production rates. The field study was not originally designed to investigate the effects of C. polylepis, and so sampling was suboptimal for this purpose. Field observations were later supplemented by experiments based on laboratory C. polylepis cultures.

\section{MATERIALS AND METHODS}

Field data presented in this paper originate primarily from daily observations between 30 May and 17 June 1988 at a permanent station in southern Kattegat 


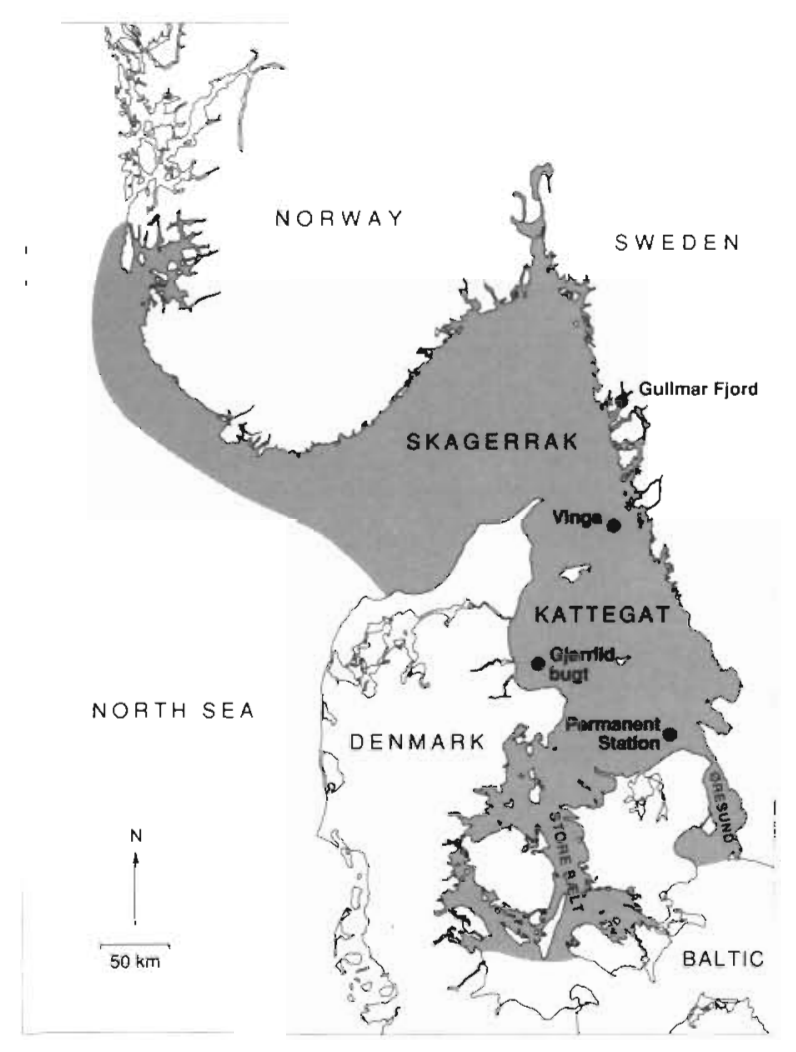

Fig. 1. Map showing the approximate horizontal distribution of the Chrysochromulina polylepis bloom (shaded area; after Berge et al. 1988) and the position of the stations ( $\bullet$ ) sampled during the present investigation

$\left(56^{\circ} 11.40 \mathrm{~N}, 12^{\circ} 04.50 \mathrm{E}\right.$, Fig. 1) at $22 \mathrm{~m}$ depth. Additional observations on vertical distributions were obtained on June 2, 1988, during a cruise with RV 'Gunnar Thorson' at 2 stations in central and northern Kattegat (Fig. 1).

Sampling. Vertical profiles of temperature, salinity, oxygen and fluorescence were recorded on all sampling occasions. Temperature and salinity were measured using a Salinity-Temperature Bridge [Type M.C.5, Electronic Switchgear (London) Ltd] and oxygen content was measured by an oxygen meter (Model 57 Yellow Spring Instruments $C D$, Ohio; the oxygen meter was calibrated in air prior to each measurement). Data were recorded every meter from surface to bottom. Fluorescence was measured with a $Q$ Instruments in situ fluorometer connected to an $X-Y$ plotter. At the permanent station, water was collected at 5 depths using a $30 \mathrm{l}$ Niskin water sampler for analysis of nutrients $\left(\mathrm{PO}_{4}^{3-}, \mathrm{NO}_{3}^{-}\right)$and chlorophyll. From the CTD and fluorescence profile 3 'intensive' sampling depths were selected: (1) surface $(2.5 \mathrm{~m})$, (2) depth of maximum fluorescence $=$ pycnocline, and (3) below the pycnocline $(17.5 \mathrm{~m})$, for determination of primary production, particle concentration, bacterial abundance and production, abundance of autotrophic and heterotrophic nanoflagellates, and microzooplankton. Subsamples for all measurements were taken from the same water sample.

Nutrients $\left(\mathrm{NO}_{3}^{-}, \mathrm{PO}_{4}^{3-}\right.$ ) were measured with an autoanalyzer (Olsen \& Lundgren 1984). Samples for chlorophyll a measurements were placed in the dark in a coldroom, and within $3 \mathrm{~h}$ after collection water samples were filtered onto GF/F filters. Samples from the 'Gunnar Thorson' cruise were extracted in $96 \%$ ethanol (Jespersen \& Christoffersen 1987), while $90 \%$ acetone was used at the permanent station. The latter samples were corrected for phaeopigments according to Lorentzen (Strickland \& Parsons 1968). Spectrophotometrical determinations were carried out on a Perkin Elmer 554.

Particle concentration and size distribution were determined on water samples within $3 \mathrm{~h}$ of collection by a Coulter Multisizer fitted with a $140 \mu \mathrm{m}$ orifice tube. In the samples from the pycnocline, Chrysochromulina polylepis cells appeared as a pronounced peak at ca 6 um in the size distribution and their abundance was estimated using the Coulter Counter. The identity of the $6 \mu \mathrm{m}$ particle as $C$. polylepis was verified by optical microscopy and on several occasions also by electron microscopy (J. Larsen, Institut for Sporeplanter, University of Copenhagen).

Primary production was measured in situ at the permanent station. Water from the 3 intensively-studied depths had ${ }^{14} \mathrm{CO}_{2}(1 \mu \mathrm{Ci} / 10 \mathrm{ml})$ added under subdued light and $9 \mathrm{ml}$ subsamples were distributed in 6 replicate $20 \mathrm{ml}$ glass scintillation vials. These vials were incubated in a frame mounted horizontally on a weighted wire and placed at the sampling depths. In addition, 3 to 6 replicates of water from the Chrysochromulina polylepis layer were incubated at the surface in frames containing filters attenuating light, to simulate light intensity at $2.5 \mathrm{~m}$ depth as recorded by a spherical quantum sensor (400 to $700 \mathrm{~nm}$ ).

Bacterial numbers were quantified by the acridine orange technique (Hobbie et al. 1977). At least 400 bacteria were counted on each filter under an Olympus $\mathrm{BH}-2$ epifluorescence microscope equipped with an $\mathrm{Hg}$ light source, at $1250 \times$.

Bacterial production was measured using the ${ }^{3} \mathrm{H}$ thymidine incorporation technique (Fuhrmann \& Azam 1980). Incorporated ${ }^{3} \mathrm{H}$-thymidine was converted to cell production by a conversion factor of $1.1 \times 10^{18}$ cells mol $^{-1}$ thymidine incorporated (Riemann et al. 1987). In order to ensure that the low incorporation rates observed in the bloom layer were not simply due to isotope dilution by dissolved thymidine, isotope dilution of thymidine incorporation was assessed on 2 June at 2.5 and $10 \mathrm{~m}$ depths by adding different concentrations of ${ }^{3} \mathrm{H}$-thymidine (1 to $40 \mathrm{nM}$ ). Lineweaver- 


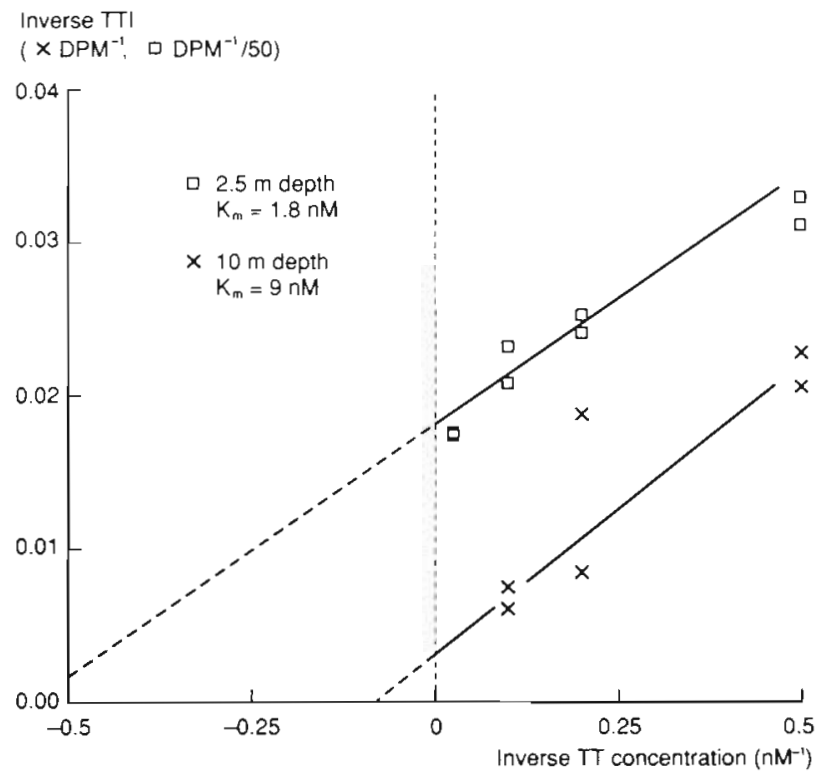

Fig. 2. Lineweaver-Burke plots of ${ }^{3} \mathrm{H}$-thymidine incorporation (TTI) against concentration of added ${ }^{3} \mathrm{H}$-thymidine, 30 May 1988 at at 2.5 and $10 \mathrm{~m}$. The inverted TTI-value from $2.5 \mathrm{~m}$ has been multiplied by 50 . Estimated half saturation concentration $\left(K_{\mathrm{m}}\right)$ and ${ }^{3} \mathrm{H}$-thymidine assuming Michaelis-Menten kinetics are given

Burke plots revealed half saturation concentrations of thymidine of $1.8 \mathrm{nM}$ at the surface, and $9 \mathrm{nM}$ at the pycnocline (Fig. 2). These half saturation constant were used to correct the standard measurements at $10 \mathrm{nM}$ ${ }^{3} \mathrm{H}$-thymidine additions into estimates of maximum incorporation rates.

The abundances of autotrophic and heterotrophic nanoflagellates were determined by epifluorescence microscopy on preparations stained with proflavine hemisulfate (Haas 1982). Samples were fixed with glutaraldehyde $(0.5 \%$ final concentration). After filtration, filters were dried, mounted in paraffin oil and stored in the refrigerator. Discrimination between autotrophic and heterotrophic nanoflagellates was faciliated using green excitation to reveal pure chlorophyll autofluorescence. The diameter was measured on ca 50 cells per station, and the biovolume was calculated assuming spherical shape. Clearance of heterotrophic flagellates was calculated as biovolume $\times 10^{5} \mathrm{~h}^{-1}$ (Fenchel 1986).

Replicate 11 samples for the enumeration of ciliates, nauplii and copepodites were preserved in $1 \%$ Lugols solution. Due to the low abundance of ciliates, samples were concentrated on an $11 \mu \mathrm{m}$ mesh net after $>24 \mathrm{~h}$ preservation, transferred to a $25 \mathrm{ml}$ settling chamber, and counted and identified using an inverted microscope. This method can be considered quantitative according to Tiselius (1989). Ciliates were identified on the basis of Leegard (1915), Kahl (1932) and Lynn et al.
(1988). Biomass was estimated from measurements of linear dimensions, assuming simple geometrical shapes and a carbon to volume ratio of 0.071 (Fenchel \& Finlay 1983).

Depth integrated zooplankton samples (>50 $\mu \mathrm{m}$ ) were collected by a submersible pump (400 $1 \mathrm{~min}^{-1}$ ) fitted with a $50 \mu \mathrm{m}$ net. The pump was lowered through the water column at $10 \mathrm{~m} \mathrm{~min}^{-1}$. Samples were preserved in $2 \%$ buffered formalin. Zooplankters in samples or subsamples were later counted and identified, and in the case of copepods, classified into eggs, nauplii, copepodites, and adult females and males.

Copepod egg production was determined according to Kiørboe et al. (1985). Adult females were sampled above the pycnocline using a $200 \mu \mathrm{m}$ WP-2 net. Within $3 \mathrm{~h}$ of collection, fertilized females were sorted and placed in $600 \mathrm{ml}$ bottles ( 3 to 5 individuals in each) containing either surface water or water from the pycnocline containing natural concentrations of Chrysochromulina polylepis. Bottles were incubated for 22 to $24 \mathrm{~h}$ on a rotating wheel $(0.5 \mathrm{rpm})$ at in situ temperature $\left( \pm 2{ }^{\circ} \mathrm{C}\right)$. At the end of the incubation, spawned eggs were counted.

Vertical profiles of micro- and meso-zooplankton were determined using a $30 \mathrm{l}$ water sampler at up to 11 depths from the surface down to $17.5 \mathrm{~m}$. Sampling was most intensive around the pycnocline where the Chrysochromulina polylepis bloom was located. For microzooplankton 11 samples of water were preserved in $1 \%$ Lugols iodine. Zooplankters in the remaining volume (29l) were collected on a $45 \mu \mathrm{m}$ sieve and preserved in buffered formaline $(2 \%$ final concentration). Vertical profiles of mesozooplankton at stations in central and northern Kattegat were obtained by submersible pump.

Laboratory experiments. Phytoplankton (Rhodomonas baltica, Heterocapsa triquetra and Chrysochromulina polylepis) were grown on $\mathrm{F}_{2}$ medium (Guillard 1975) in either continuous or repeated batch cultures at a constant dilution rate $\left(1 / 3 \mathrm{~d}^{-1}\right)$ and with an illumination of ca $100 \mu \mathrm{E} \mathrm{m}^{-2} \mathrm{~s}^{-1}$. C. polylepis was isolated from the Kattegat during the present bloom by J. Larsen (Institut for Sporeplanter, University of Copenhagen). A culture of the ciliate Favella ehreabergii originating from the Limfjord, Denmark, was provided by $\mathrm{P}$. J. Hansen (Marine Biological Laboratory) and copepods Acartia tonsa were obtained from a laboratory culture (Støttrup et al. 1986). The following experiments were all carried out on a rotating wheel $(0.5$ rpm) at $17 \pm 1{ }^{\circ} \mathrm{C}$ and $29 \% \mathrm{~S}$ and under dim light conditions. The effect of $C$. polylepis on the growth of $F$. ehrenbergii was studied by adding $50 \mathrm{~F}$. ehrenbergii (with micropipettes) to each of seven $64 \mathrm{ml}$ Nuclon Bottles (made of polystyrene); 6 containing $4 \times 10^{3}$ Heterocapsa triquetra $\mathrm{ml}^{-1}$ and from 0 to $30 \times 10^{3} \mathrm{C}$. 
polylepis $\mathrm{ml}^{-1}$, and 1 with algal medium which served as a starvation control. Bottles were inspected daily and ciliates were counted and transfered to new bottles containing fresh algal suspensions. One experiment was carried out during the bloom using the natural population of $C$. polylepis at concentrations between 20 and $60 \times 10^{3}$ cells $\mathrm{ml}^{-1}$. This experiment differs from the one mentioned above in that single ciliates were incubated in $2 \mathrm{ml}$ algal suspension in Nuclon multidishes (24 chambers, made of polystyrene) without circulation.

Clearance, ingestion and egg production rates of the copepod Acartia tonsa were determined at 6 concentrations of either Chrysochromulina polylepis or Rhodomonas baltica, as well as in mixtures of the two. $R$. baltica was selected as control species since it is very similar in size to $C$. polylepis ( 6.9 and $6 \mu \mathrm{m}$ equivalent spherical diameter, respectively). For each concentration, 6 to 8 fertilized females were added to each of four $600 \mathrm{ml}$ bottles; 2 bottles without copepods served as controls. Clearance and ingestion rates were measured following $72 \mathrm{~h}$ incubation and calculated by the equation of Frost (1972). The algal concentrations at the start and end of incubations were counted with a Coulter Counter. During the subsequent $4 \mathrm{~d}$ egg production was measured. Copepods were transferred daily to new bottles containing fresh algal suspensions and spawned eggs were counted. Only egg production rates from the last $2 \mathrm{~d}$ were used to ascertain that equilibrium with the ingestion rate had been reached. At the end of the experiment the cephalothorax length of 10 females was measured, and carbon contents calculated from the regression in Berggreen et al. (1988). The carbon content of eggs was assumed to be $46 \mathrm{ng} \mathrm{C} \mathrm{egg}{ }^{-1}$ (Kiørboe et al. 1985).

The effect of Chrysochromulina polylepis filtrate on ${ }^{3} \mathrm{H}$-thymidine incorporation in bacterioplankton was studied as follows: water was collected at the permanent station and at a station off Helsingor Harbor in April or May 1989. Mixed bacterioplankton batch cultures were prepared from water filtered through Whatman GF/C filters and kept at the in situ temperature for $3 \mathrm{~d}$ prior to use. At the beginning of the experiment cultures were diluted $50 \%$ with sterile filtrates (0.45 um cellulose nitrate filters) of Rhodomonas baltica or C. polylepis culture media (50 and $100 \times 10^{3}$ cells $\mathrm{ml}^{-1}$, respectively). Sterile filtered $\mathrm{F}_{2}$ medium was used as a control. Thymidine incorporation rate was measured at hourly intervals during the next 8 to $10 \mathrm{~h}$.

Fig. 3. Temporal variation in vertical profiles of salinity, temperature, nutrients $\left(\mathrm{NO}_{3}^{-}, \mathrm{PO}_{4}^{3-}\right)$, in situ fluorescence and chiorophyll a at the permanent station between 30 May and 17 June 1988. Dots show sampling depths. Lower panel shows variation in windspeed and direction $(24 \mathrm{~h}$ average) at a coastal station ca $20 \mathrm{~km}$ from the permanent station (Danish Meteorological Institute)

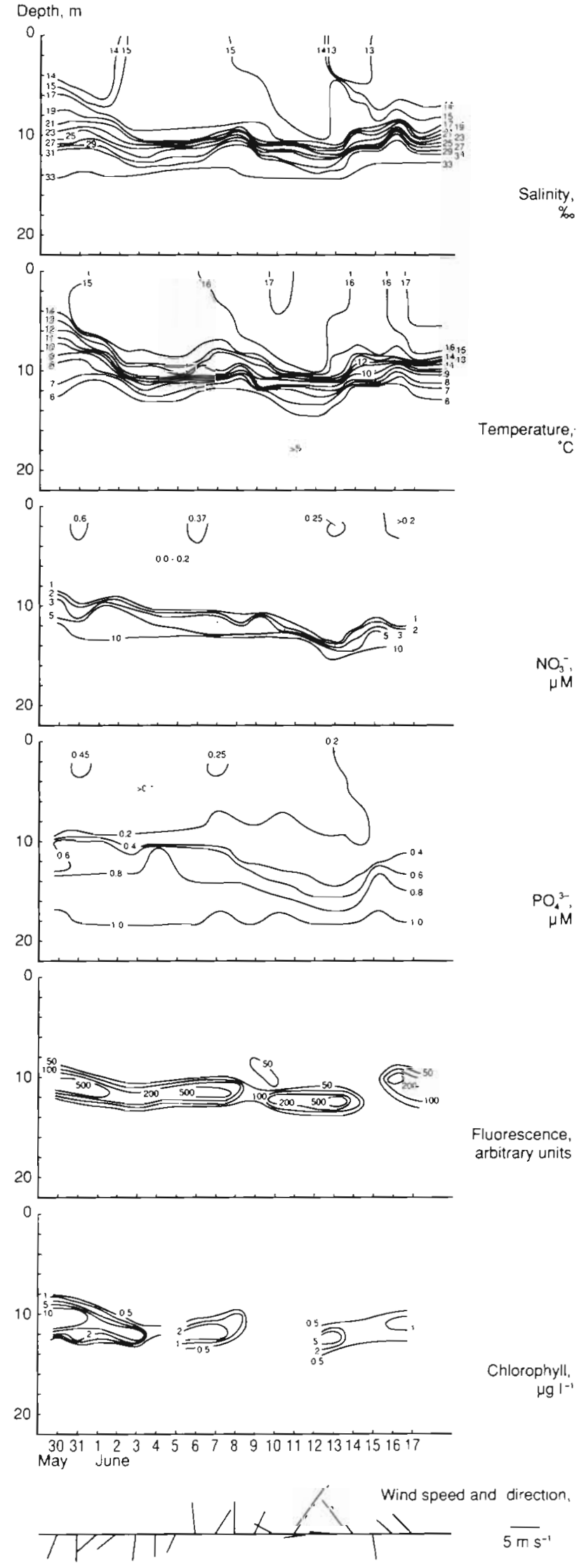




\section{RESULTS}

Vertical distributions of temperature, salinity, nitrate, phosphate, fluorescence and chlorophyll at the permanent station between 30 May and 16 June are shown in Fig. 3. Throughout the period there was a pronounced pycnocline at 10 to $12 \mathrm{~m}$ depth, primarily generated by salinity differences. Below the pycnocline the salinity exceeded $33 \%$, whereas the salinity in the surface layer varied between 12 and $15 \%$. The variable surface salinity is due to variable horizontal advection of water from the outflowing Baltic current or from the surface of northern Kattegat, depending on wind speed and direction (Fig. 3). At times, advection from the Baltic current resulted in the establishment of a secondary pycnocline at 5 to $6 \mathrm{~m}$ e.g. 30 May to 2 June, 8 to 10 June, 12 to 14 June.

Coinciding with the primary halocline there was significant increase in $\mathrm{NO}_{3}^{-}$(Fig. 3); nitrate concentrations of surface waters were close to the detection limit, and bottom concentrations were $>10 \mu \mathrm{M}$. The distribution of phosphate showed a similar, but less pronounced pattern, with surface concentrations between 0.1 and $0.3 \mu \mathrm{M}$ and a bottom concentration around $1 \mu \mathrm{M}$.

A pronounced subsurface chlorophyll maximum was associated with the pycno- and nutricline. Initially this layer consisted of a monospecific bloom of Chrysochromulina polylepis, but after June 3 other phytoplankters also occurred (Table 1). At the beginning of the period the concentration of chlorophyll a was $>10$ $\mu \mathrm{g} \mathrm{I}^{-1}$ in the pycnocline, whereas chlorophyll a in surface water was less than $0.5 \mu \mathrm{g} \mathrm{l}^{-1}$ throughout the period. There was a general decline in plant pigment concentration at the pycnocline during the period, although the pattern was somewhat erratic. A similar pattern was shown by the concentration of C. polylepis cells in the pycnocline (Table 1). We suggest that the general decline in plant pigments and concentrations of C. polylepis cells illustrates the declining subsurface bloom from its height around June 1 to its disappearance in mid-June. The variation around this general trend is most likely due to horizontal patchiness and horizontal advection. This is supported by the fact that increases in pigment concentration at the pycnocline

Table 1. Chrysachromulina polylepis. Abundance (cells $\mathrm{ml}^{-1}$ $\times 10^{3}$ ) in the pycnocline counted by the Coulter Counter in 1988. Bloom was defined as monospecific (x) when C. polylepis constituted $>95 \%$ of the biovolume

\begin{tabular}{|lccccccccccc|}
\hline & \multicolumn{11}{c|}{ Date (day.month) } \\
& 30.5 & 31.5 & 1.6 & 2.6 & 3.6 & 6.6 & 7.6 & 8.6 & 13.6 \\
\hline Concentration & 41 & 43 & 41 & 66 & 16 & 14 & 16 & 8 & 10 \\
Monospecific & $\mathrm{x}$ & $\mathrm{x}$ & $\mathrm{x}$ & $\mathrm{x}$ & & & & & \\
\hline
\end{tabular}

during the period were preceded by changes in wind direction, and presumably in direction of currents (Fig. 3).

Because of horizontal advection our data for one location do not represent a true succession in the plankton community. However, because of the large horizontal distribution of the bloom (Fig. 1), the concentration (Table 1), growth (Table 2) and appearance of Chrysochromulina polylepis cells, we refer our vertical profiles and sampling of heterotrophs to 3 periods or phases of the bloom: (1) The height of the bloom (30 May to 2 June), with relative high pigment and cell concentration in the pycnocline and healthy looking $C$. polylepis cells with a high growth rate and growth potential (Table 2). (2) The decaying bloom (June 3 to 10) with intermediate pigment and cell concentration. At this stage the majority of the $C$. polylepis cells were dead or dying and overgrown by bacteria (observed by fluorescence microscopy). They had a lower growth rate and growth potential (Table 2). (3) The reference situation, subsequent to the bloom (after June 14), when only scales of $C$. polylepis were present in the pycnocline

Table 2. In situ and potential primary production (incubated in the surface) in water sampled in the pycnocline $(10$ to $12.5 \mathrm{~m})$ at the permanent station. -: no measurements

\begin{tabular}{|rcccc|}
$\begin{array}{r}\text { Date } \\
\text { (day. } \\
\text { mo })\end{array}$ & $\begin{array}{c}\text { Primary production } \\
\left(\mu \mathrm{g} \mathrm{C} \mathrm{l}^{-1} \mathrm{~h}^{-1}\right)\end{array}$ & $\begin{array}{c}\text { Assimilation ratio } \\
\left(\mu \mathrm{g} \mathrm{C} \mu \mathrm{g} \mathrm{chl} \mathrm{a}^{-1} \mathrm{~h}^{-1}\right)\end{array}$ \\
\hline In situ & Potential & In situ & Potential \\
\hline 30.5 & 14.5 & - & 1.3 & - \\
31.5 & 12.4 & 47.0 & 1.1 & 4.3 \\
1.6 & 12.4 & 60.0 & 1.9 & 6.7 \\
8.6 & 1.69 & 5.2 & 1.1 & 3.5 \\
16.6 & 0.56 & 1.2 & 0.3 & 0.64 \\
\hline
\end{tabular}

During the height of the bloom bacterial abundance was greatest in the surface water, despite chlorophyll concentration being about 20 times higher in the pycnocline (Table 3). From June 3 the highest abundance of bacteria was invariably found in the pycnocline together with maximum chlorophyll values. Bacterial production was very low in the pycnocline during the height of the bloom. However, much higher activity was subsequently (from June 3) measured at this depth (Table 4). These profiles suggest that Chrysochromulina polylepis may have an inhibitory effect on bacterial production and this suggestion was substantiated by laboratory experiments. Natural bacterioplankton, whether collected at the permanent station in southern Kattegat or at a site outside Helsingør Harbor, showed significantly lower thymidine incorporation rates when incubated with $C$. polylepis filtrate than 
Table 3. Vertical distribution of bacterial abundance (cells $\times 10^{6} \mathrm{ml}^{-1}$ ) with depth (m) for bacterioplankton during the 3 wk sampling at the permanent station

\begin{tabular}{|c|c|c|c|c|c|c|c|c|c|c|c|c|c|c|}
\hline \multirow[t]{2}{*}{ Depth } & \multicolumn{14}{|c|}{ Date (day. month) } \\
\hline & 30.5 & 31.5 & 1.6 & 2.6 & 3.6 & 4.6 & 6.6 & 7.6 & 8.6 & 9.6 & 10.6 & 14.6 & 15.6 & 16.6 \\
\hline 2.5 & 3.0 & 3.3 & 2.6 & 2.5 & 1.1 & 1.7 & 2.0 & 1.8 & 1.9 & 2.4 & 1.9 & 1.6 & 1.6 & 0.8 \\
\hline 10 & 1.7 & 1.8 & 1.4 & 1.3 & - & - & - & - & - & - & - & - & - & - \\
\hline 12.5 & - & - & - & - & 4.1 & 2.8 & 3.0 & 3.8 & 2.7 & 2.9 & 6.3 & 2.7 & 2.8 & 5.6 \\
\hline 17.5 & 1.1 & 1.2 & 1.1 & - & 1.3 & 1.4 & 1.1 & 1.3 & 1.3 & 1.6 & 1.2 & - & 0.6 & 0.7 \\
\hline
\end{tabular}

when incubated with Rhodomonas baltica filtrate or algal medium (Fig. 4). Thymidine incorporation rate in the harbor bacterioplankton started to decline after 5 to $6 \mathrm{~h}$ incubation, reaching nearly zero after $9 \mathrm{~h}$. This decline may simply be caused by exhaustion of organic substrate.

Concentrations of heterotrophic nanoflagellates were within the range of published values for coastal waters $\left(1\right.$ to $\left.5 \times 10^{3} \mathrm{ml}^{-1}\right)$; however, no heterotrophic flagellates were observed in the pycnocline during the bloom peak (Table 5).

Ciliates were absent from the pycnocline until June 7. whereafter their abundance increased to 1000-1500 $\mathrm{l}^{-1}$ equivalent to a biomass of 0.4 to $0.8 \mu \mathrm{g} \mathrm{Cl}^{-1}$ (Fig. 5B). The ciliate fauna was numerically dominated by oligotrichs, in particular Lohmaniella oviformis, but the abundance of the tintinnids Helicostomella subulata and Tintinnopsis sp. increased towards the end of the period. Surface ciliates were present throughout the period at concentrations ranging from 300 to $800 \mathrm{1}^{-1}$, equivalent to a biomass of between 0.5 and $2.7 \mu \mathrm{g} \mathrm{C} 1^{-1}$ (Fig. 5A). In general the ciliate fauna was more diverse at the surface than in the pycnocline. Initially naked oligotrichs dominated; tintinnids only occurred towards the end of the period.

The vertical distribution of the dominating ciliate species confirms the effect of Chrysochromulina polylepis. On May 31, during the height of the bloom, ciliates were absent from the pycnocline but occurred both above and below the bloom (Fig. 6). By June 8 the bloom was declining, the pycnocline contained decaying algae and all dominating ciliate species were pres- ent. Several species showed maximum abundance in the pycnocline (Lohmaniella oviformis, Helicostamella subulata and Tintinnopis sp.). This ciliate distribution pattern, with local maxima around the pycnocline, is explained by the model of Jonsson (1989) as an effect of reduced turbulence towards the pycnocline. Ciliates were again maximally abundant in the pycnocline on June 16, when only scales of $C$, polylepis were found there. The change in ciliate abundance and vertical distribution suggests that $C$. polylepis has a deleterious effect on protozoa.

Growth experiments with Favella ehrenbergii incubated in water collected from the pycnocline on June 2 (Fig. 7A) showed that its growth is inhibited in the presence of $6 \times 10^{4}$ Chrysochromulina polylepis cells $\mathrm{mI}^{-1}$ (natural concentration). The effect is concentration dependent, but it was evident even at the lowest concentration tested $\left(2 \times 10^{4}\right.$ cells $\left.\mathrm{ml}^{-1}\right)$.

These results were confirmed by the growth/survival response of Favella ehrenbergii to different concentrations of cultured Chrysochromulina polylepis (Fig. 7B). Exposure of $F$. ehrenbergii to Heterocapsa triquetra results in tumbling when the ciliate bumps into the cells. The swimming behavior of the ciliates was, however, unaffected by the presence of C. polylepis, even at the highest concentrations, indicating that $C$. polylepis was not ingested. This observation is supported by laboratory and field studies on the food size spectrum of $F$. ehrenbergii, illustrating that only cells between 15 and $35 \mu \mathrm{m}$ are ingested (Stoecker et al. 1981, Fenchel 1987). At concentrations below $10^{4}$ C. polylepis $\mathrm{ml}^{-1}$ ciliates were able to survive and grow

Table 4. Vertical distnbution of bacterial production (cells $\times 10^{3} \mathrm{ml}^{-1} \mathrm{~d}^{-1}$ ) with depth $(\mathrm{m})$ at the permanent station

\begin{tabular}{|c|c|c|c|c|c|c|c|c|c|c|c|c|c|c|}
\hline \multirow[t]{2}{*}{ Depth } & \multicolumn{14}{|c|}{ Date (day.month) } \\
\hline & 30.5 & 31.5 & 1.6 & 2.6 & 3.6 & 4.6 & 6.6 & 7.6 & 8.6 & 9.6 & 10.6 & 14.6 & 15.6 & 16.6 \\
\hline 2.5 & 232 & 106 & 61 & 155 & 22 & 40 & 55 & 37 & 66 & 38 & 68 & 109 & 185 & 1.49 \\
\hline 7.5 & 154 & 64 & 13 & - & 43 & 28 & 55 & 40 & 78 & 110 & 113 & 230 & 165 & 88 \\
\hline 10 & 2 & 1 & 0 & 20 & - & - & - & - & - & 125 & - & 335 & - & 346 \\
\hline 12.5 & 11 & 1 & 0 & - & 885 & 226 & 55 & 250 & 1.62 & 290 & 1300 & 606 & 824 & 43 \\
\hline 1.7 .5 & 5 & 5 & 0 & - & 131 & 83 & 37 & 70 & 64 & 125 & 110 & 83 & 63 & 54 \\
\hline
\end{tabular}


at rates similar to fed controls; at concentrations exceeding $10^{4}$ cells $\mathrm{ml}^{-1}$ they eventually died off, although at concentrations below $3 \times 10^{4}$ cells $\mathrm{ml}^{-1}$ ciliates grew during the first day; at $3 \times 10^{4}$ cells $\mathrm{ml}^{-1}$ ciliates died almost as fast as starved controls. At high concentrations of $C$. polylepis, $F$. ehrenbergii lose their loricas and shrink, as do unfed ciliates.

The abundance of copepods in the surface layer remained relatively constant (30 to $60 \mathrm{l}^{-1}$ ) during the entire period, exceeding the pycnocline values until 7 June (Fig. 8). For the pycnocline, however, copepod abundance was initially low (ca $20 \mathrm{l}^{-1}$ ), but on June 8 copepods apparently invaded this layer as evidenced by the several-fold increase in abundance between
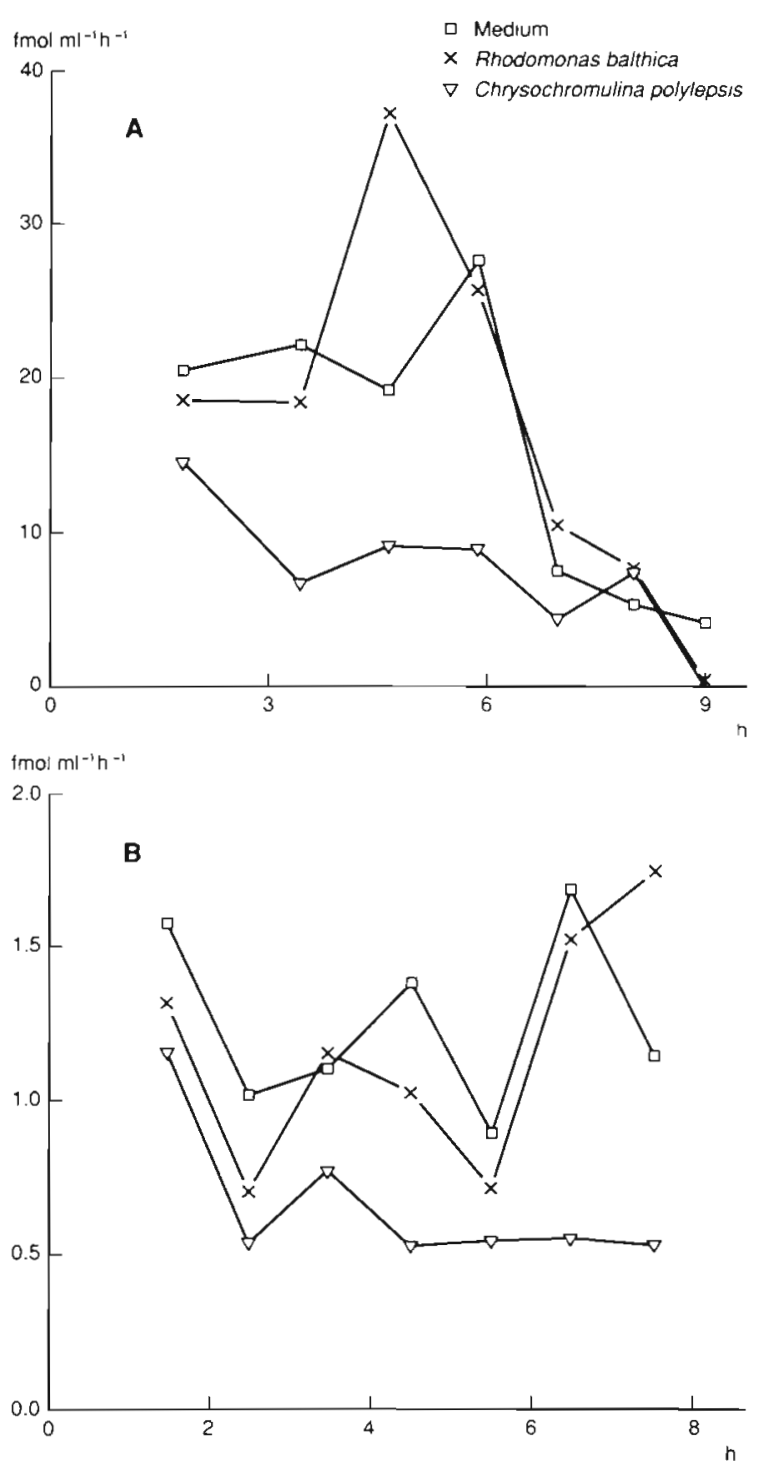

Fig. 4. Time series of ${ }^{3} \mathrm{H}$-thymidine incorporation in natural bacterioplankton collected at a site outside Helsingør Harbor (A) and at the permanent station (B) with addition of filtrates of Rhodomonas baltica, Chrysochromulina polylepis or algal media
Table 5. Numbers of heterotrophic nanoflagellates $\left(10^{3}\right.$ cells $\mathrm{ml}^{-1}$ ) determined by epifluorescence microscopy. Mean cell volume was $30 \mathrm{\mu m}^{3}$, ( $\left.\mathrm{n}=205\right)$. Note: assuming a nanoflagellate clearance of $10^{5}$ body volume $\mathrm{h}^{-1}$, a population of $10^{3} \mathrm{ml}^{-1}$ will exert a grazing rate of $7 \% d^{-1}$

\begin{tabular}{|lccc|}
\hline Layer & \multicolumn{3}{c|}{ Date (day.month) } \\
& 30.5 & 6.6 & 8.6 \\
\hline Surface layer & 1.6 & 5.3 & 0.9 \\
Pycnocline & 0.0 & 1.1 & 0.9 \\
Bottom layer & 1.6 & 1.2 & 0.9 \\
\hline
\end{tabular}

7 and 8 June (Fig. 8B). After this date the pycnocline abundance of copepods exceeded that at the surface. Unfortunately, the vertical distribution of copepods was not examined at the permanent station at the height of the bloom. However, pooled samples (18 l) collected at the pycnocline between 30 May and 2 June contained only 1.8 adults, 2.9 copepodites and 3.4 nauplii $\mathrm{I}^{-1}$,

Number $I^{-1}$ (thousands)

$\mu g \mathrm{Cl}^{-1}$
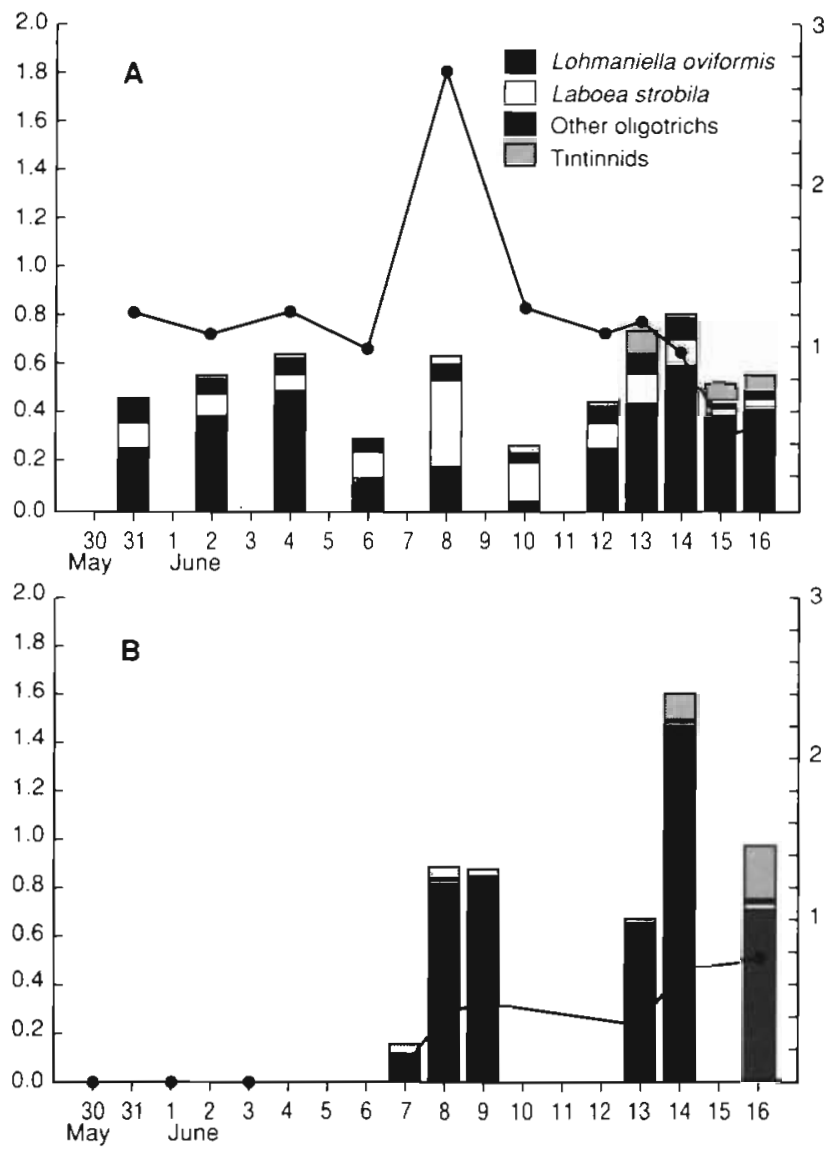

Fig. 5. Time series of abundance (bars, number $\mathrm{I}^{-1}$ ) and biomass of ciliates (continuous line, $\mu \mathrm{g} \mathrm{C}^{-1}$ ) at the permanent station at $(\mathrm{A})$ the surface $(2.5 \mathrm{~m})$ and $(\mathrm{B})$ the pycnocline (10 to $12.5 \mathrm{~m})$ 
whereas similar samples from surface waters contained 5.0 adults, 8.8 copepodites and 20 nauplii $\mathrm{l}^{-1}$. Vertical distributions (on 2 June) at 'Gjerrild Bugt' (Fig. 1) confirmed this pattern (Fig. 9A). This station exhibited a monospecific bloom of Chrysochromulina polylepis $\left(8 \times 10^{4}\right.$ cells $\left.\mathrm{ml}^{1}\right)$ in the pycnocline where the concentration of copepods was virtually zero. In contrast, the concentration of copepods (copepodites and adults) was $>30 \mathrm{l}^{-1}$ both immediately above and below the pycnocline. During the declining phase of the bloom (June 8) and subsequent to the bloom (June 16), the vertical profile of copepod distribution showed the opposite pattern, with maximum concentration in the pycnocline (Fig. 9C, D). This vertical pattern was especially pronounced for older development stages (copepodites and adults). The vertical distribution of copepodites and adults at the northern 'Vinga' station on June 2 (Fig. 9B) resembles this pattern - with peak abundance at the pycnocline. At this station the con- centration of C. polylepis cells was moderate $\left(2.7 \times 10^{4}\right.$ $\mathrm{ml}^{-1}$ ) and the bloom was mixed with an unidentified dinoflagellate. Because pump samples from the permanent station show that the total copepod biomass remained relatively constant between 30 May and 16 June (Table 6), the vertical distribution patterns observed were caused by avoidance of, or accumulation in, the pycnocline rather than an increase in abundance following the bloom.

Egg production rates of the 3 dominant copepod species were generally lower when incubated with Chrysochromulina polylepis compared to those incubated in surface waters (Table 7). Females incubated in water from the subsurface bloom were observed to have slower reactions and greater mortality during $24 \mathrm{~h}$ incubation than those incubated in surface water (Table 8). The yellow guts of surviving copepods indicated that $C$. polylepis had been ingested during incubation.
A
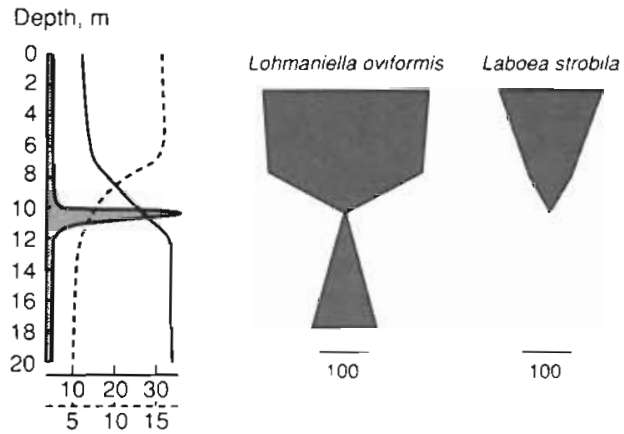

Lohmanella oviformis
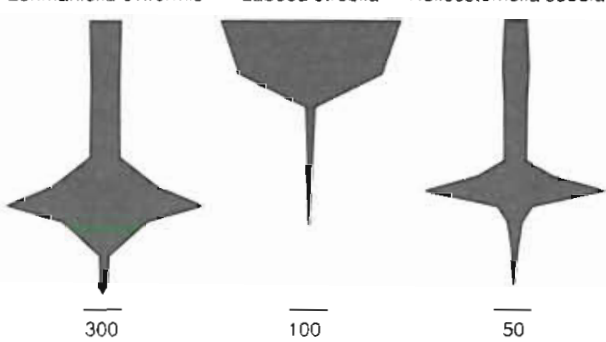

C

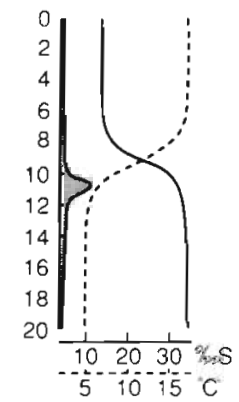

Lohmaniglla oviormis

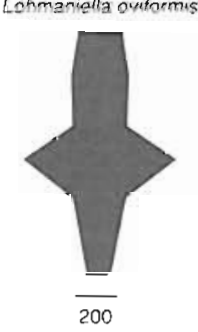

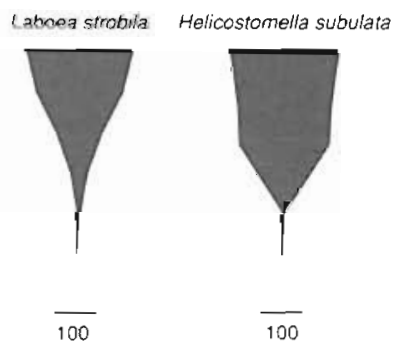
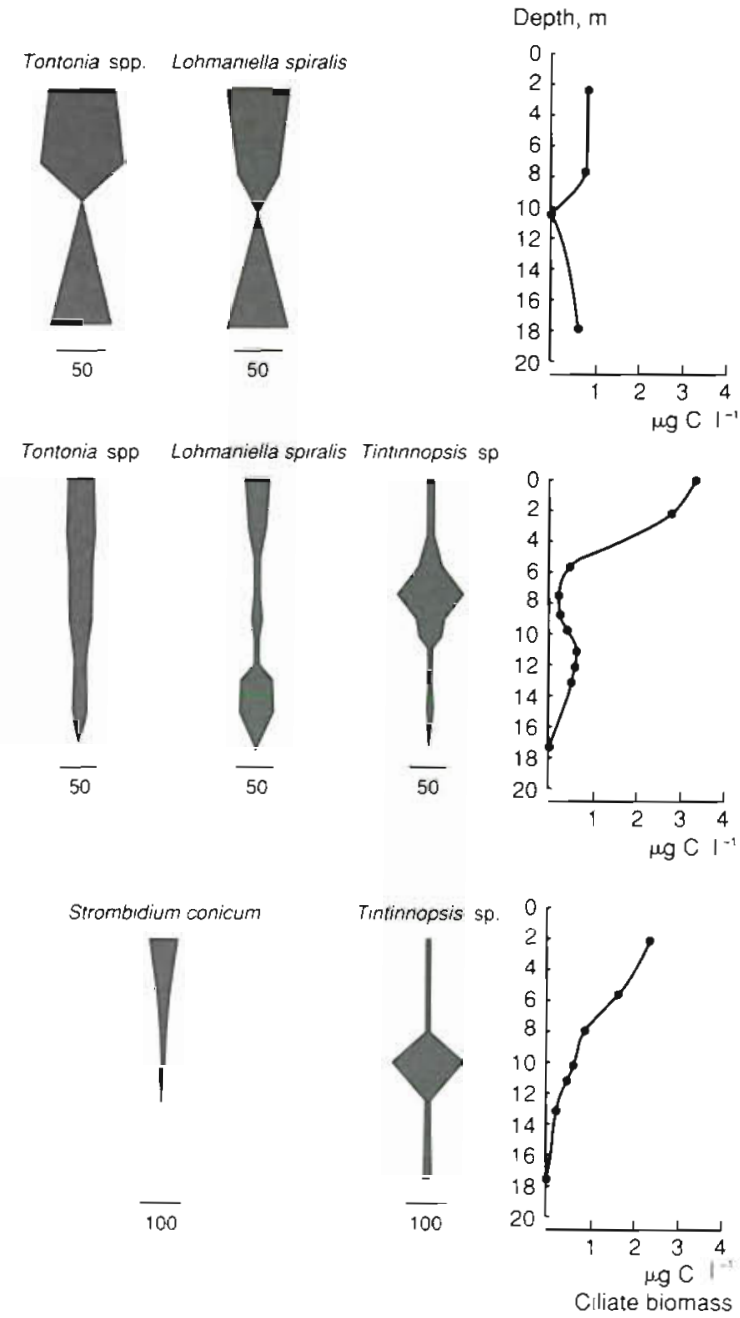

Fig. 6. Profiles (left) of temperature $\left({ }^{\circ} \mathrm{C}\right.$, dotted line), salinity $(\%$, continuous line) and fluorescence (arbitrary unxts, shaded area); vertical distribution (center) of the dominant ciliates (bars indicate scales in number of ciliates $\mathrm{I}^{-1}$ ) and total (right) crliate biomass ( $\mu \mathrm{g} \mathrm{C}^{-1}$ ) at the permanent station on 3 sampling occasions: (A) 31 May, (B) 8 June, (C) 16 June 1988 
Number of ciliates
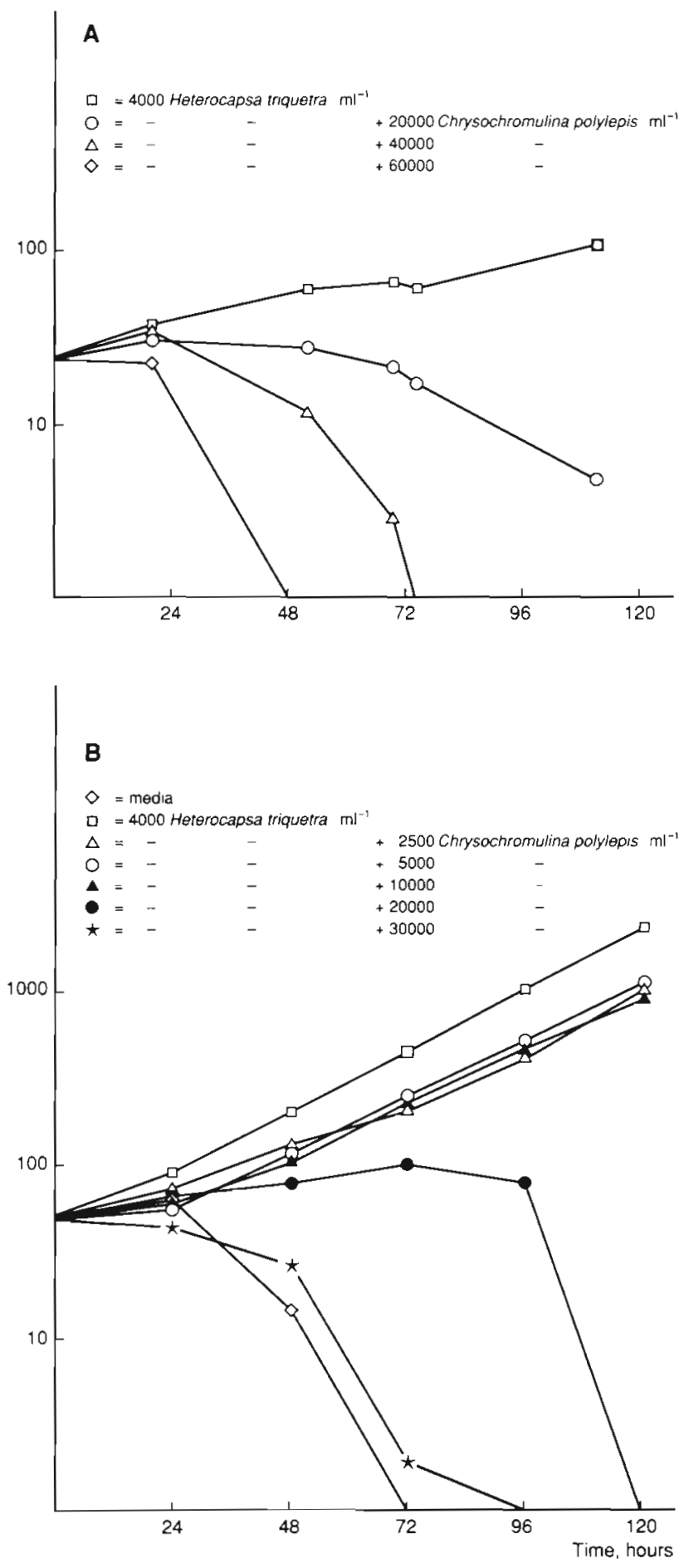

Fig. 7. Favella ehrenbergui. Growth and survival response to different concentrations of Chrysochromulina polylepis. In all experiments 4000 Heterocapsa triguetra $\mathrm{ml}^{-1}$ were added. (A) Experiments conducted during the height of the bloom (2 June 1988) using water from the pycnocline at the permanent station (Per Juel Hansen unpubl. data). (B) Experiments conducted using cultivated $C$. polylepis isolated from samples taken from the permanent station
This conclusion is only partially supported by laboratory experiments with cultures of Chrysochromulina polylepis. The clearance and ingestion of C. polylepis by Acartia tonsa and its egg production were significantly lower than values obtained at the same concentrations of Rhodomonas baltica (Fig. $10 \mathrm{~A}$ to $C$ ). In experiments where $A$. tonsa was offered a mixture of $C$. polylepis and $R$. baltica cells, however, egg production was unaffected by the concentration of C. polylepis cells up to ca 5 ppm (ca $4 \times 10^{4}$ cells $\mathrm{ml}^{-1}$; see Fig. 10D). Daily mortality rates for all laboratory incubations were insignificant $\left(<5 \% \mathrm{~d}^{-1}\right)$ and independent of the presence of $C$. polylepis. These results suggest that $A$. tonsa avoided feeding (or fed at lower rate) on cultivated $C$. polylepis cells, but that the laboratory culture was not toxic to copepods at the concentrations tested.
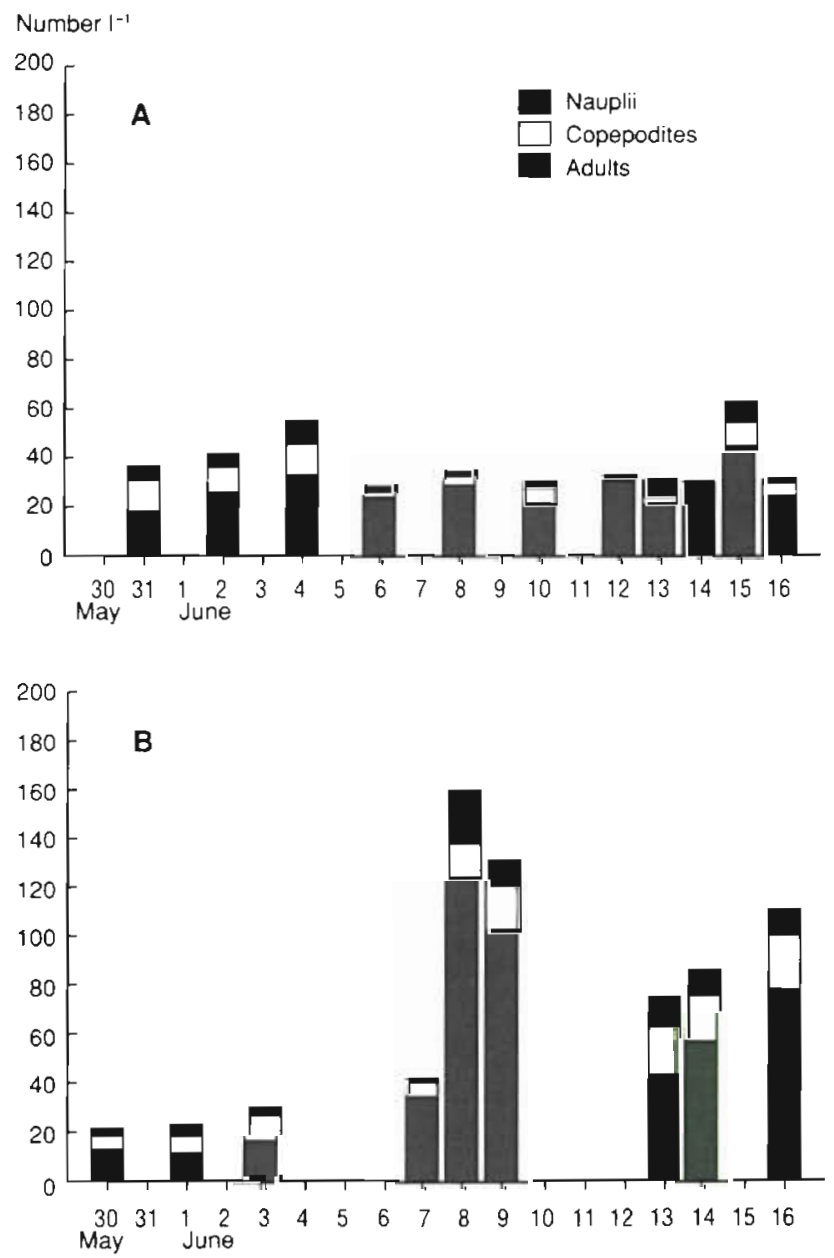

Fig. 8. Time series of abundance of different copepod stages in (A) the surface $(2.5 \mathrm{~m})$ and $(B)$ the pycnocline $(10$ to $12.5 \mathrm{~m})$ at the permanent station. The copepod community was dominated by Oithona spp., Acartia spp. and Centropages hamatus at the surface, while Oitona spp., Pseudocalanus sp. and Microstella norwegica dominated in the pycnocline 

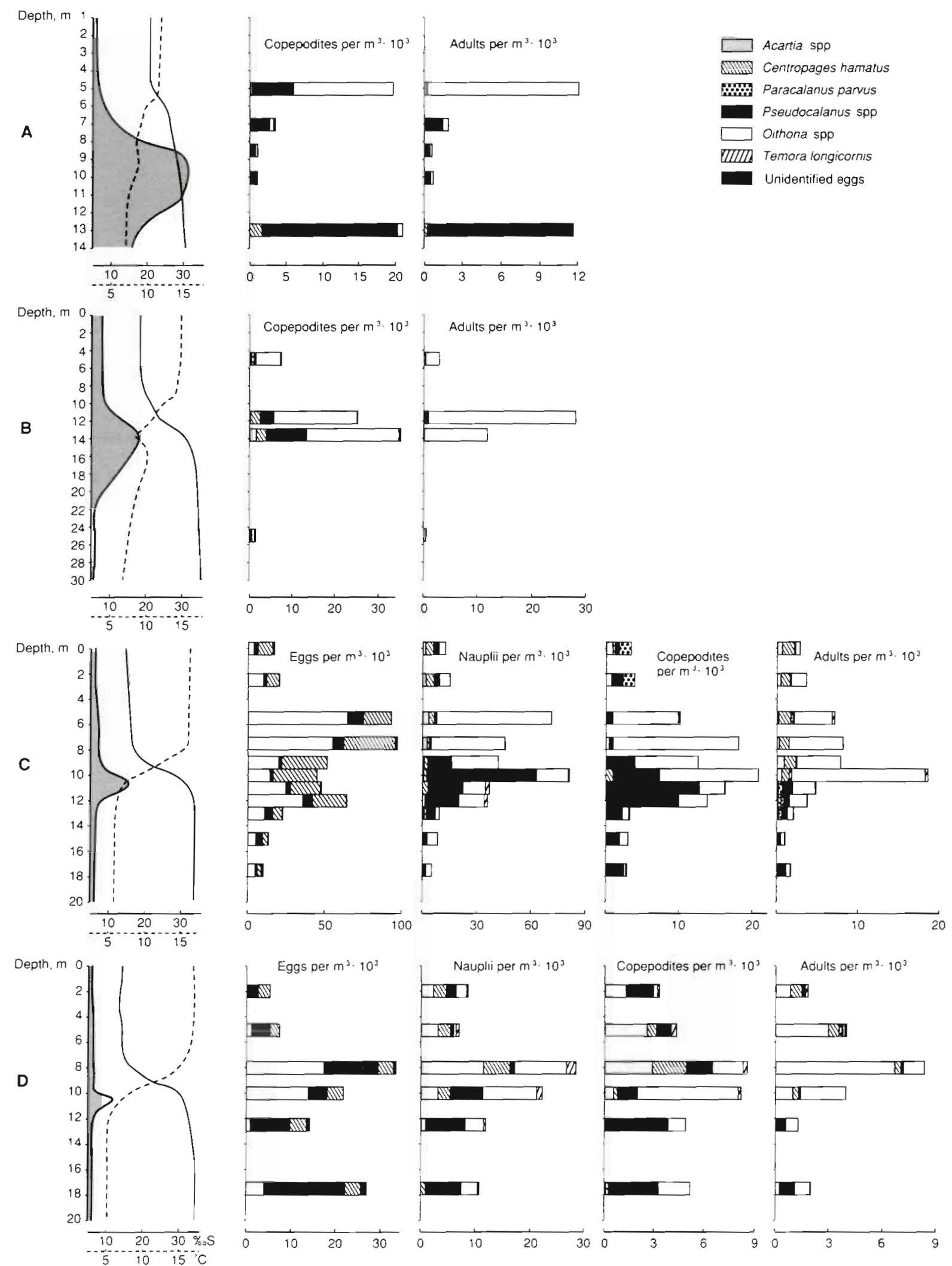

Fig. 9. Profiles (left) of temperature $\left({ }^{\circ} \mathrm{C}\right.$, dotted line), salinity (\%, continuous line) and fluorescence (arbitrary units, shaded area) and vertical distribution (right) of the dominating copepod species on 4 sampling occasions. (A) Gjerrild Bugt, June 2, 1988; (B) Vinga, June 2,1988; (C) the permanent station, June 8, 1988; and (D) the permanent station, June 16, 1988 
Table 6 . Biomass ( $\mathrm{mg}$ dry $w \mathrm{~m}^{-2}$ ) of dominating copepods species in vertical pump-samples at the permanent station in 1988

\begin{tabular}{|lccccrr|}
\hline Date & $\begin{array}{c}\text { Oithona } \\
\text { spp. }\end{array}$ & $\begin{array}{c}\text { Pseudocalanus } \\
\text { sp. }\end{array}$ & $\begin{array}{c}\text { Acartia } \\
\text { spp. }\end{array}$ & $\begin{array}{c}\text { Centrophages } \\
\text { hamatus }\end{array}$ & $\begin{array}{c}\text { Temora } \\
\text { longicornis }\end{array}$ \\
\hline 30 May & 249 & 270 & 73 & 18 & 47 & 657 \\
1 June & 263 & 772 & 263 & 102 & 49 & 1450 \\
3 June & 410 & 491 & 206 & 43 & 33 & 1202 \\
7 June & 199 & 353 & 72 & 134 & 25 & 1009 \\
10 June & 169 & 591 & 326 & 90 & 22 & 818 \\
14 June & 173 & 197 & 515 & 89 & 10 & 1201 \\
16 June & 207 & 335 & & & & \\
\hline
\end{tabular}

Table 7. Egg production rates (eggs female $\mathrm{d}^{-1} \pm \mathrm{SD}$; number of determinations given in parenthesis) of copepods incubated in surface water or water from the pycnocline containing high concentrations of Chrysochromulina polylepis. Data from 19 May and 21 to 25 March originates from Gullmar Fjord (Fig. 1), and were provided by Peter Tiselius (pers. comm)

\begin{tabular}{|c|c|c|c|c|}
\hline & \multicolumn{2}{|c|}{ With C. polylepis } & \multicolumn{2}{|c|}{ 'Normal' rates } \\
\hline & 19 May & 30 May & 21-25 March & 1-16 June \\
\hline Temperature $\left({ }^{\circ} \mathrm{C}\right)$ & 11 & 10.5 & $3-4$ & 14 \\
\hline C. polylepis conc. (cells $\mathrm{ml}^{-1}$ ) & $14 \times 10^{3}$ & $65 \times 10^{3}$ & 0 & 0 \\
\hline Acartia sp. & $\begin{array}{c}0.2 \pm 0.4 \\
(6)\end{array}$ & $\begin{array}{c}0 \\
(6)\end{array}$ & $\begin{array}{c}6.9 \pm 1.7 \\
(7)\end{array}$ & $\begin{array}{c}13.8 \pm 2.2 \\
(15)\end{array}$ \\
\hline Centropages hamatus & $\begin{array}{c}2.6 \pm 3.6 \\
\text { (5) }\end{array}$ & $\begin{array}{c}4.8 \pm 2.6 \\
(6)\end{array}$ & $\begin{array}{c}23.4 \pm 6.0 \\
(7)\end{array}$ & $\begin{array}{c}11.7 \pm 4.5 \\
(10)\end{array}$ \\
\hline Temora longicornis & $\begin{array}{c}0 \\
(1)\end{array}$ & $\begin{array}{c}5.1 \pm 4.8 \\
(6)\end{array}$ & - & $\begin{array}{c}9.4 \pm 3.6 \\
(5)\end{array}$ \\
\hline
\end{tabular}

Table 8. Mortality of copepods $\left(\% \mathrm{~d}^{-1}\right)$ during egg production experiments (May 30) in water from the pycnocline and in surface water during the bloom (no. experiments in parenthesis)

\begin{tabular}{|lcc|}
\hline Species & $\begin{array}{c}\text { Surface } \\
\text { water }\end{array}$ & $\begin{array}{c}\text { Water with } \\
\text { Chrysochromulina }\end{array}$ \\
\hline Acartia sp. & $6 \%$ & $30 \%$ \\
Centropages hamatus & $(15)$ & $(6)$ \\
Temora longicornis & $(9)$ & $13 \%$ \\
& 0 & $(6)$ \\
& $(6)$ & $21 \%$ \\
\hline
\end{tabular}

\section{DISCUSSION}

Subsurface blooms in the Kattegat have not often been observed in the past (Nicolaisen \& Christensen 1986). However, our unpublished data indicate that a subsurface nanoflagellate bloom may be a recurrent phenomena in the Kattegat area during May and June. After the spring bloom, the transparent surface water contains few nutrients, surface phytoplankton biomass is low, but flagellates develop in the pycnocline where they may be supplied by nutrients from below and light from above.
The calm and sunny weather during May 1988 presumably favored the development of the Chrysochromulina polylepis bloom. On average there was $11.7 \pm 3.8 \mathrm{~h}$ sunshine $\mathrm{d}^{-1}$ from May 9 to 31. A general change in weather conditions coincided with the end of the bloom - the average sunshine hours during the first week of June decreased to $5.0 \pm 3.6 \mathrm{~h} \mathrm{~d}^{-1}$. (Data obtained from a coastal station $20 \mathrm{~km}$ from the permanent station, Danish Meterological Institute.)

The fairly high rates of primary production (Table 2) as well as a pronounced oxygen supersaturation $(130 \%)$ in the pycnocline, suggest that the present bloom was actively growing at the density interface rather than passively being accumulated there. These subsurface flagellate blooms in the Kattegat appear, generally, to consist of mixtures of algal species (including flagellates of the genus Chrysochromulina) (Dahl et al. in press, own unpubl. obs.), whereas the present bloom was monospecific. The reasons for the development of this monospecific blooms remain unclear (see Dahl et al. in press).

Several reports show that marine phytoplankton species are toxic or unpalatable to both ciliates and copepods; toxic species are found mainly among Dinophyceae (e.g. Huntley et al. 1986, Hansen 1989 , Uye \& Takamatsu 1990), but deleterious effects of vari- 


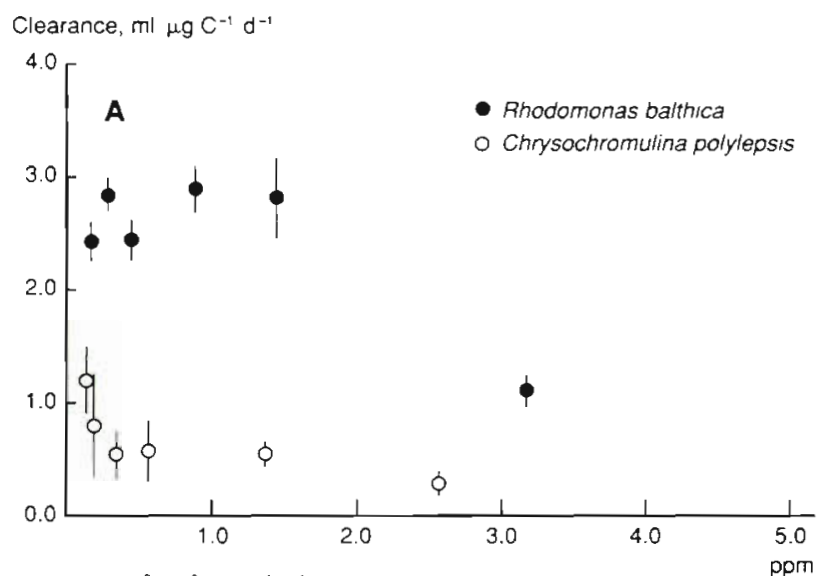

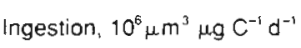

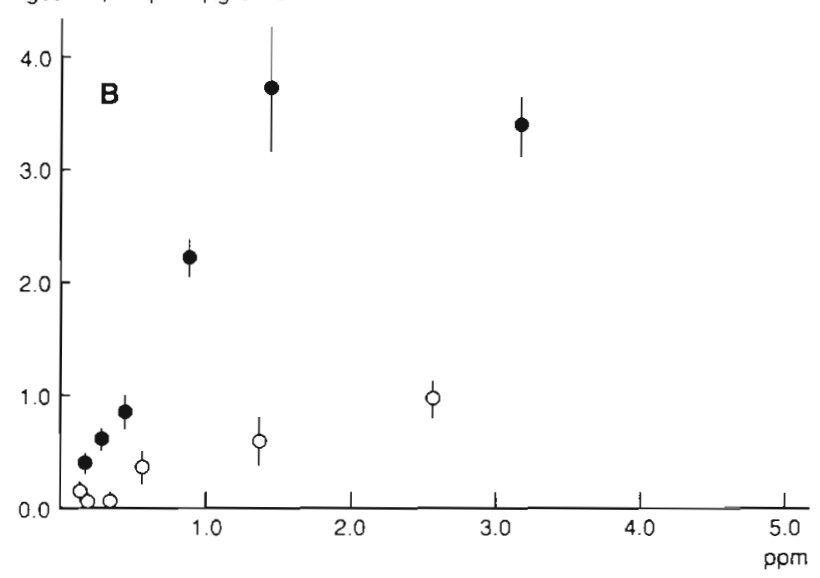

Egg production, $\mu g \mathrm{C} \mu g \mathrm{C}^{-1} \mathrm{~d}^{-1}$

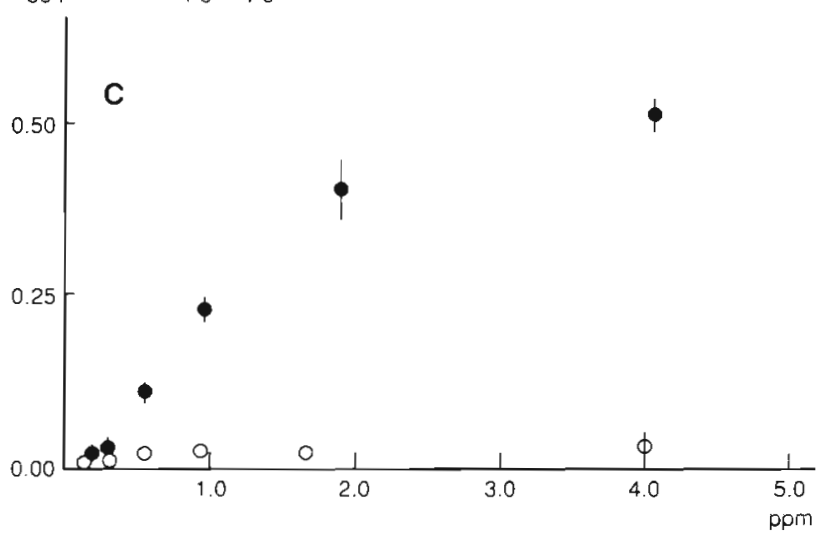

Egg production. $\mu g \mathrm{C} \mu g \mathrm{C}^{-1} d^{-1}$

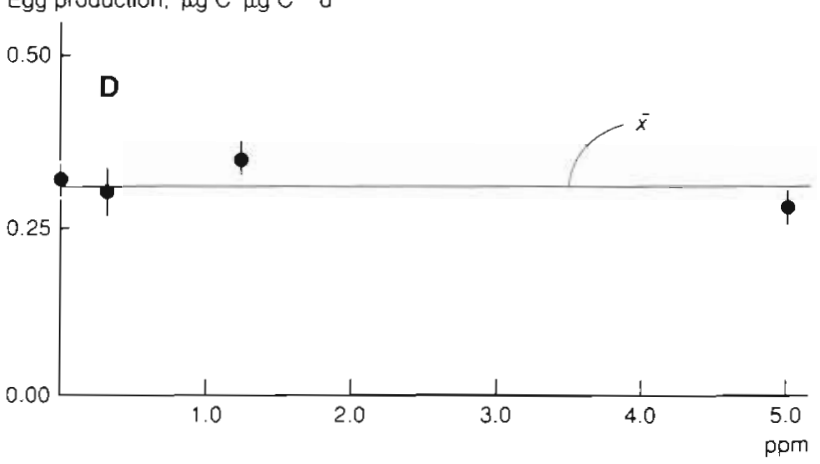

ous Raphidophyceans to ciliates (Verity \& Stoecker 1982) and copepods (Uye \& Takamatsu 1990) have also been documented. Among the Haptophyceans there is evidence that Phaeocystis pouchtii is toxic, unpalatable or at least of low nutritional value to copepods (e.g. Tande \& Båmsted 1987, Riswijk et al. 1989, Verity \& Smayda 1989), and Prymnesium parvum is known to produce substances that are toxic to fish (e.g. Shilo 1981, Kozakai et al. 1982). In the present study we have documented the deleterious effects of the haptophycean Chrysochromulina polylepis to both prokaryote and eukaryote components of the plankton community.

A tight coupling between bacterial production and algal biomass or production is usually assumed (e.g. Cole et al. 1988). During the Chrysochromulina polylepis bloom, the highest bacterial biomass and activity was measured in the surface water, even though the algal biomass and primary production was several times higher in the pycnocline. Studies on uptake kinetics show that the low thymidine incorporation in the bloom layer was not simply due to isotope dilution. In their description of C. polylepis, Manton \& Parke (1962) reported that phagotrophy was common and that organisms and graphite particles up to $3 \mu \mathrm{m}$ in diameter were ingested. Phagotrophy is also known to occur in related species e.g. C. spinifera (Pineaar \& Norris 1979). The low bacterial biomass in the maximum chlorophyll layer could, therefore, be explained as an effect of grazing. However, laboratory experiments conducted during the bloom, using inert fluorescent particles, could not confirm the observation of Manton \& Parke (L. Berg pers. comm.). The potential bacterial grazing by heterotrophic flagellates was significantly lower in the pycnocline than at the surface water during the bloom (Table 3) and, thus, also cannot explain the low bacterial abundance in the pycnocline.

The low incorporation rate of thymidine in the pycnocline suggests that the low biomass was due to low bacterial production rather than grazing. Together with the laboratory experiments, this suggests that Chrysochromulina polylepis has a deleterious effect on natural populations of bacteria. Other species of unicellular algae have been reported to produce extracellular antibiotic substances (rewiewed by Hellebust 1973). This is, to our knowledge, the first example of inhibitory effects of $C$. polylepis on bacterioplankton. Not all marine bacteria are affected, however, since bacteria thrived in laboratory cultures of C. polylepis.

Fig. 10. Acartia tonsa, adult females. (A) Clearance, (B) ingestion rate and $(C)$ egg production at vanous concentrations of Chrysochromulina polylepis ( $\Rightarrow$ ) or Rhodomonas baltica (•). In (D) A. tonsa were offered mixtures of $R$. baltica (1.25 ppm) and C. polylepis (0 to $5.0 \mathrm{ppm}$ ). Clearance rates in (A) calculated for one Coulter Counter channel 6.35 to $8.0 \mu \mathrm{m}$ equivalent spherical diameterj. All values are means \pm SEM 
The vertical distribution of heterotrophic flagellates, ciliates and copepods at the height of the bloom, as well as the laboratory experiments with the 2 latter groups, also suggest deleterious effects on both protozoan and metazoan plankton. While the low abundance of bacteria in the Chrysochromulina polylepis layer is most likely due to a depressing effect on growth rate, swimming organisms have the potential to avoid the layer. Fiedler (1982) showed how different species of mesozooplankton actively avoided a dense layer of Gymnodinium splendens in southern California Bright, USA, and there are several examples of negative correlation between the occurrence of proven toxic or unpalatable phytoplankton species and copepods (Huntley 1982, Holligan et al. 1984) and ciliates (Verity $\&$ Stoecker 1982). Such an avoidance response may be due to excretion of noxious substances by phytoplankters. Our observations of reduced swimming activity by copepods incubated in $C$. polylepis containing water will also contribute to the exclusion of copepods from the pycnocline.

It is not clear whether the vertical distribution patterns are due to (sub)lethal effects of Chrysochromulina polylepis, behavioral responses, or both. The incubation experiments with the ciliate Favella ehrenbergii suggest inhibitory effects at C. polylepis concentrations $>10^{4}$ cells $\mathrm{ml}^{-1}$, since incubated ciliates died out even in the presence of palatable food. The results for copepods are equivocal, since no effect with Acartia tonsa feeding on palatable cells was observed in experiments with mixtures of Rhodomonas baltica and different concentrations of cultivated C. polylepis. Also, even though $A$. tonsa feeding and egg production were insignificant on a pure diet of cultivated C. polylepis, no lethal effects were evident. When incubated with natural populations of $C$. polylepis, however, swimming activity and egg production in different species of copepods was significantly reduced, and mortality rate significantly increased.

Toxic effects of the Chrysochromulina polylepis bloom in Scandinavian waters have been reported for other groups of organisms including fish, bottom invertebrates (Granmo et al. 1988, Rosenberg et al. 1988) and even thallophytes (Rosenberg et al. 1988). We also observed that Ceratium spp. cells occurring in the $C$. polylepis layer during the bloom were obviously moribund, since their cytoplasm had shrunk and pigmentation was lost. A similar observation was reported by Dahl et al. (in press).

It is often assumed that the production of substances by phytoplankton, that render them unpalatable or toxic to grazers, provides a mechanism by which monospecific blooms may form and be maintained (e.g. Stedinger \& Baden 1984). Since the Chrysochromulina polylepis bloom in Scandinavian waters during the spring of 1988 apparently had deleterious effects on all heterotrophic components of the plankton community tested, and perhaps also on potentially competing phytoplankton species, this most likely contributed significantly to the formation of the bloom. However, $C$. polylepis occurs regularly in Scandinavian waters but has not previously been reported as bloom forming, neither here nor elsewhere (Taylor 1985). Also, previous reports on this species explicitly note that it is nontoxic to fish (Manton \& Parke 1962). Jerebram (1980) noted that it provides excellent food for bryozoans, although senescent cultures become slightly toxic to bryozoans. Finally, Norwegian isolates have not shown toxicity to a random selection of test organisms (Dahl et al. in press) and the toxicity of our isolate to copepods was different from that of the natural population. This suggest that toxicity of $C$. polylepis may not be a constant feature, but may vary among strains or with the physiological status of the algae. In the closely related Prymnesium parvum, toxicity is enhanced in phosphorus depleted cells (Shilo 1981) and preliminary investigations (quoted in Dahl et al. in press) suggest that this may also be the case for $C$. polylepis. However, vertical profiles of $\mathrm{NO}_{3}^{-}$and $\mathrm{PO}_{4}^{3-}$ at the permanent station (Fig. 2) suggest that $N$ rather than $P$ was the limiting nutrient, and that the P:N ratio was in excess of the Redfield ratio. This explanation, therefore, seems not to apply to the C. polylepis population in southern Kategat or in our laboratory culture, and other explanations for its toxicity must be sought.

After June 3 the bloom became senescent and cells were colonized by bacteria. By June 7 to 8 , Chrysochromulina polylepis had apparently lost its toxicity to eukaryote organisms, the pycnocline was rapidly invaded by heterotrophic flagellates, ciliates and copepods, and the pelagic food-web resumed a more normal structure.

Acknowledgements. We are grateful to Tom Fenchel and Per Juel Hansen for valuable critisism and discussion. We thank Knut Yngve Borsheim, Vagn Olsen, Katherine Richardson, Peter Tiselius, Per Juel Hansen and Flemming Møhlenberg for letting us use their unpublished data. We are indebted to Jack Melby and Lisbeth Olsen for technical assistance, Peter Haxen for computer assistance and to the crew of the R V 'Ophelia', Benly Thrue and Bent Jørgensen for help with sampling. We acknowledge grants from the Danish Environmental Protection Agency (HF-90, 2-03B) and grants nos 11-6925 and 11-6480 from the Danish Natural Science Research Council

\section{LITERATURE CITED}

Barth, H., Nielsen, A. (1989). The occurrence of Chrysochromulina polylepis in the Skagerrak and Kattegat in May/June 1988: an analysis of extent, effects and causes. Commission of the European Communities, Luxembourg. Water pollution research report 10 
Berge, J. A., Green, N., Rygg, B., Skulberg, O. (1988). Invasion of the plankton alga Chrysochromulina polylepis along the coast of southern Norway in May-June 1988. Immediate effect on the coastal ecosystem. Part A. Concluding rapport. Norwegian Institute for Water Research, Governmental program for pollution survey, Rept. $328 \mathrm{a} / 88,44$ pp. (In Norwegian)

Berggreen, U., Hansen, B., Kiørboe, T. (1988). Food size spectra, ingestion and growth of the copepod Acartia tonsa: implication for the determination of copepod production. Mar. Biol. 99: 341-352

Christensen, T., Koch, C., Thomsen, H. A. (1985). Distribution of algae in Danish salt and brackish waters. Univ. Copenhagen. Universitetbogladen, Copenhagen

Cole, J. J., Findlay, S., Pace, M. L. (1988). Bacterial production in fresh and saltwater ecosystems: a cross-system overview. Mar. Ecol. Prog. Ser. 43: 1-10

Dahl, E., Lindahl, O., Paasche, E., Throndsen, J. (in press). The Chrysochromulina polylepis bloom in Scandinavian waters during spring 1988. In: Cosper, E. M. et al. (eds.) A novel phytoplankton bloom. Causes and impacts of recurrent brown tides. Springer Lecture Notes on coastal and estuarine studies

Edler, L. (1984). A mass development of Ceratium species on the swedish west coast. Limnologica, Berlin 15 (2): 353-357

Fenchel, T. (1986). Protozoan filter feeding. Prog. Protistol. 1. 63-113

Fenchel, T. (1987). Ecology of protozoa. The biology of freeliving phagotrophic protists. Springer-Verlag, Berlin

Fenchel, T., Finlay, B. J. (1983). Respiration rates in heterotrophic free-living protozoa. Microb. Ecol. 9: 99-122

Fiedler, P. (1982). Zooplankton avoidance and reduced grazing responses to Gymnodinium splendens (Dinophyceae). Limnol. Oceanogr 27: 961-965

Frost, B. W. (1972). Effects of size and concentration of food particles on the feeding behavior of the marine copepods Calanus pacificus. Limnol. Oceanogr. 17: 805-815

Fuhrman, J. A., Azam, F. (1980). Bacterioplankton secondary production estimates for coastal waters off British Columbia, Antartica and California. Appl envirl Microbiol. 39: 1085-1095

Granmo, ^. Havenhand, J., Magnusson, K., Svane, I. (1988). Effects of the planktonic flagellate Chrysochromulina polylepis Manton et Park on fertilization and early development of the acidian Ciona intestinalis (L.) and the blue mussel Mytilus edulis L. J. exp. mar. Biol. Ecol. 124: $65-71$

Guillard, R. R. L. (1975). Culture of phytoplankton for feeding marine invertebrates. In: Smith, W. L., Chanley, M. H. (eds.) Culture of marine invertebrate animals. Plenum, New York, p. 29-60

Haas, L. W. (1982). Improved epifluorescence microscopy for observing planktonic micro-organisms. Ann. Inst. oceanogr., Paris 58 (suppl.): 261-266

Hansen, P. J. (1989). The red tide dinoflagellate Alexandrium tamarense: effects on behavior and growth of a tintinnid ciliate. Mar. Ecol. Prog. Ser. 53: 105-116

Hellebust, J. A. (1973). Extracellular products, In: Stewart, W D. P. (ed.) Algal physiology and biochemistry. Blackwell scientific Publications, Oxford, p. 838-863

Hobbie, J. E., Daley, R. J., Jaspers, S. (1977). Use of nucleopore filters for counting bacteria by epiflourescence. Appl. envirl Microbiol. 33: 1225-1228

Holligan, P. M., Harris, R. P., Newell, R. C., Harbour, D. S., Head, R. N., Linley, E. A. S., Lucas, M. I., Tranter, P. R. G., Weekley, C. M. (1984). Vertical distribution and partitioning of organic carbon in mixed, frontal and stratified waters of the English Channel. Mar. Ecol. Prog. Ser. 14: $111-127$

Huntley, M. E. (1982). Yellow water in La Jolla Bay California, July 1980. II. Suppression of zooplankton grazing. J. exp. mar. Biol. Ecol. 63: 81-91

Huntley, M. E., Sykes, P., Rhoan, S., Martin, V. (1986). Chemically-mediated rejection of dinoflagellate prey by the copepods Calanus pacificus and Paracalanus parvus: mechanism, occurrence and significance. Mar. Ecol. Prog. Ser. 28: $105-120$

Jebram, D. (1980). Prospectives for a sufficient nutrition for the cosmopolitic marine bryozoan Electra pilosa (Linnaeus). Zool. Jb. (Abt. Syst. Okol. Geogr. Tiere) 107: 368-390

Jespersen, A.-M., Christoffersen, K. (1987). Measurement of chlorophyll a from phytoplankton using ethanol as extraction solvent. Arch. Hydrobiol. 109 (3) : 445-454

Jonsson, P. R. (1989). Vertical distribution of planktonic ciliates - an experimental analysis of swimming behaviour. Mar. Ecol. Prog. Ser. 52: 39-53

Kahl, A. (1932). Urtiere oder Protozoa. I. Wimpertiere oder Ciliata (Infusoria). 3. Spirotricha. In: Dahl, F, (ed). Die Tierwelt Deutschlands und der angrenzenden Meeresteile. Gustav Fisher Verlag, Jena

Kiørboe, I., Møhlenberg, F., Riisgaard, H. U. (1985). In situ feeding rates of planktonic copepods: a comparison of four methods. J. exp. mar. Biol. Ecol. 88: 67-81

Kozakai, H., Oshima, Y., Yasamoto, T. (1982). Isolation and structural elucidation of hemolysin from the phytoflagellate Prymnesium parvum. Agric. biol. Chem. 46: 233-236

Leegard, C. (1915). Untersuchungen über einige planktonciliaten des Meeres. Nyt. Mag. Naturvid. 53: 1-37

Lindahl, O. (1983). On the development of a Gyrodinium aureulum occurrence on the Swedish west coast in 1982 Mar Biol. 77: 143-150

Lynn, D. J., Montagnes, D. J. S., Small, E. B. (1988). Taxonomic descriptions of some conspicuous species in the family Strombidiidae (Ciliophora: Oligotrichida) from the Isles of Shoals, Gulf of Maine. J. mar. biol. Ass. U. K. 62 (2): 252-259

Manton, I., Parke, M. (1962). Preliminary observations on scales and their mode of origin in Chrysochromulina polyJepis sp. nov. J. mar. biol. Ass. U.K. 42: 565-578

Nicolaisen, W., Christensen, H. (1986). Pelagic turnover and transport to the bottom of particulate organic material in the northern Øresund. Ophelia 26: 317-332

Olsen, V., Lundgren, B. (1984). A compact eight-channel continuous flow analyzer for shipboard use. Comm. Meet. Int. Counc. Explor. Sea C.M.-ICES/C: 19

Pienaar, R. N., Norris, R. E. (1979). The ultrastructure of the flagellate Chrysochromulina spenifera (Fournier) comb. nov. (Prymnesiophycea) with special reference to scale production. Phycologia 18 (2): 99-108

Riemann, B., Bjornsen, P. K., Newell, S., Fallon, R. (1987). Calculation of cell production of coastal marine bacteria based on measured incorporation of $\left[{ }^{3} \mathrm{H}\right]$ Thymidine. Limnol. Oceanogr. $32(2): 471-476$

Rijswijk, P. van, Bakker, C., Vink, M. (1989). Daily fecundity of Temora longicornis (Copepoda, Calanoida) in the Oosterschelde estuary (SW netherlands) Neth. J. Sea. Res. 23 (3) : 293-303.

Rosenberg, R., Lindahl, O., Blanck, H. (1988). Silent spring in the sea. Ambio 17 (4): 289-290

Shilo, M. (1981). The toxic principles of Prymnesium parvum. In: Carmichael (ed.) The water environment. Algal toxins and health. Plenum Press, New York, p. 37-47

Steidinger, K. A., Baden, D. G. (1984). Toxic marine dinoflagellates. In: Spector, D. L. (ed.) Dinoflagellates. Academic Press, New York, p. 201-261 
Stoecker, D., Guillard, R. R. L., Kavee, R. M. (1981). Selective predation by Favella ehrenbergii (Tintinnia) on and among dinoflagellates. Biol. Bull, mar. biol. Lab., Woods Hole 160: $135-145$

Støttrup, J. G., Richardson, K., Kirkegaard, E., Pihl, N. J (1986). The cultivation of Acartia tonsa Dana for use as a live food source for marine fish larvae. Aquaculture, Amsterdam, 52:87-96

Strickland, J. D. H., Parsons, T. R. (1968). A practical handbook of seawater analysis. Bull. Fish. Res. Bd Can. 167

Tande, K. S., Bamsted, U. (1987). On the trophic fate of Phaeocystis poucheti (Hariot). I. Copepod feeding rates on solitary calls and colonies of Phaeocystis pouchetii. Sarsia 72: 313-320

Taylor, F. J. R. (1985). The taxonomy and relationships of Red tide flagellates. In: Anderson, D. M., White, A. W., Baden,

This article was presented by Professor T. Fenchel, Helsingor, Denmark
D. G. (eds.) Toxic dinoflagellates. Elsevier, New York, p. 11-27

Tiselius, P. (1989). Contribution of alloricate ciliates to the diet of Acartia clausi and Centropages hamatus in coastal water. Mar Ecol. Prog. Ser. 56: 49-56

Uye, S., Takamatsu, K. (1990). Feeding interactions between copepods and red-tide flagellates from Japanese coastal waters. Mar. Ecol. Prog. Ser. 59: 97-107

Verity, P. G. Smayda, T. J. (1989). Nutritional value of Phaeocystis pouchetii (Prymnesiophyceae) and other phytoplankters for Acartia spp. (Copepoda): ingestion, egg production and growth and nauplii. Mar. Biol. 100: 161-171

Verity, P. G., Stoecker, D. (1982). Effect of Olisthodiscus luteus on the growth and abundance of tintinnids. Mar. Biol. 72: $79-87$

Manuscript first received: October 2, 1989

Revised version accepted: January 31, 1990 